\title{
Improving Academic Writing Skills through Online Mode of Task-Based Assignments
}

\author{
Sugeng Purwanto ${ }^{1}$ \\ ${ }^{1}$ Stikubank University Semarang, Central Java Indonesia \\ Correspondence: Sugeng Purwanto, Faculty of Language and Cultural Studies, Stikubank University Semarang, \\ Indonesia. Tel: 62-812-289-5927. Email: drpsugeng@yahoo.com
}

Received: July 3, 2016 Accepted: July 30, 2016 Online Published: August 1, 2016

doi: 10.5539/elt.v9n9p74 URL: http://dx.doi.org/10.5539/elt.v9n9p74

\begin{abstract}
This is to report a 2-Year Research Project (2015-2016) funded by the Directorate General of Higher Education of the Republic of Indonesia, which aims at justifying whether or not the online mode of task-based writing assignments (of various genres of English texts) could improve the writing skills of the students at higher education. An action research was conducted in College of Economics and Business Studies, Stikubank University (UNISBANK) Semarang, Central Java Indonesia in response to the lack of time allocated to students' writing activities in their English class. Three cycles of treatments were employed-each with five phases, (1) identification of problem area, (2) collection and organization of data, (3) interpretation of data, (4) action based on data and (5) reflection of action. The findings showed that - compared with the initial condition- there was a mean increase of $31 \%$ and an increase of $121 \%$ in the students' scores beyond the passing score of 61 . Also, the students' writing motivation increased considerably ( $>86 \%$ toward positive attitudes) as revealed in the survey at the end of the treatment program.
\end{abstract}

Keywords: academic writing skills, genre, online mode, task-based assignments

\section{Introduction}

Despite the fact that writing is an important aspect of English proficiency, it is still considered supplementary as compared to the other language skills. Only recently - as Purwanto (2015) claimed - have writing skills been specifically tested in an international English language proficiency test, such as TOEFL although IELTS had launched 'the writing test' since its inception. In the writing test, the test takers are required to write essays which are scored using a special rubric for judgment and evaluation. Meanwhile, it is evidently true that writing is never easy at all levels, even in one's own language, let alone in a foreign language such as English in Indonesian contexts. In other words, writing skills are both difficult to learn and teach.

Furthermore, Indonesian graduates of various disciplines have been said to have English proficiency levels. As Purwanto (2015) revealed, quoting AntaraNews.Com (2011) 'at the moment, only 5\% or 12 million people of the whole population are English language users in various fields of business encounters'. Indonesia was the $34^{\text {th }}$ state out of 44 states of non-English users, with score of 44.78. It is therefore ranked very low in terms of English language proficiency. According to English First (EF) proficiency index (2011), the mastery level of English is closely related to the income per capital of a country. That is the higher the level of English language proficiency of the population, the higher level of income per capital. This is very relevant to the recent context of Asian Economic Community (AEC) that would take effects in 2015. Thus, Indonesia as it belongs to the region, cannot be separated from the necessity of English mastery - in order to succeed in business competition.

Many efforts have been made with respect to developing the four language skills of English as a foreign language in Indonesia. These efforts have been undertaken in line with the recent trends in language teaching methodology, one of which is to make the best use of social networks or media, such as Facebook or Tweeter, by means of PCs, laptops, mobile phones or smartphones. It can be assumed, that everyone has access to such media. It was reported that the sales of smartphones increased by $67.6 \%$ in the first quarter of 2010 compared to the third quarter of 2009 (International Data Corporation, 2010). Thus, it is time that online media be used as an alternative mode of learning and teaching either as a sole course in itself or supplementary activities in addition to the main course of studies (combined modes of off- and on-line learning). 
With respect to the use of social network, it is reported that most students $(87 \%)$ use for 'friend making', $23 \%$ for academic access with lecturers, $12 \%$ for academic links access, and $6 \%$ for academic group discussion (Purwanto, 2013). The current study (a 2-year research grant), is therefore aimed at developing teaching materials integrated in a mobile web application system to improve the students' academic writing skills at graduate level. The use of writing skills was particularly chosen as the area of research in response to the current demand for high levels of writing competence in anticipation of the Asian Economic Community (AEC) era.

At this point, it has been presumed that software application called "Question Writer 4 (CW4)", despite its original purpose for testing, can be used as a medium of learning and teaching, by integrating a learning module into the system. It is true that the process of learning is similar to testing in which it starts with problem-solving to elicit the students' prior knowledge as a basis for further skills development. It is sort of backwash effect of testing, which enhances acquisition of skills and knowledge. It should also be noted that it does not have to be "Question Writer" (CW4) as there are possibly other similar products on the market. An action research employing Question Writer (CW3.5) in online reading assignments to increase the students' reading interests has been conducted by Rahayu and Februariyanti (2015). They found out that the students' reading interests increased considerably on completion of the online assignments.

Based on the above perceptions, two research questions can be formulated: (1) "How is each process of treatment undertaken in each cycle of learning through the online mode of task-based assignments?" and (2)"How effective is the use of a software application to improve academic writing skills through the online mode of task-based assignments?" In this respect, a learning module has to be devised and its effectiveness tested in order to come up with a rigid online module for different contexts of higher education. It is also necessary to critically evaluate the module for further revision prior to recommendations for a wider use of the learning module. The module is then integrated into a software application for online access.

\section{Method}

The current research is an action research attempting to justify the effectiveness of the online mode of task-based assignments to improve college students' academic writing skills of various genres in English. The pre-designed learning module has been integrated into a software application for the students to get online access. The software has been programmed in such a way that all students' completed assignments are automatically scored (except for essay assignments which should be manually scored employing a reliable rubric for essay judgment and evaluation) and sent back to the teacher via his or her email through the system). Thus all forms of treatments in this research were completed online, including the survey (SurveyMonkey) to examine the students' attitude, enthusiasm, and preference of the online assignments.

\subsection{Research Design}

The current study adopted Ferrance's (2000) Action Research in which an action research is performed in cycles of at least two cycles. Each cycle consists of five steps, namely (1) identification of problem area, (2) collection and organization of data, (3) interpretation of data, (4) action based on data, and (5) reflection of action. In the study, three cycles were undertaken so as to generate reliable results.

The step for each cycle is shown in Figure 1. 


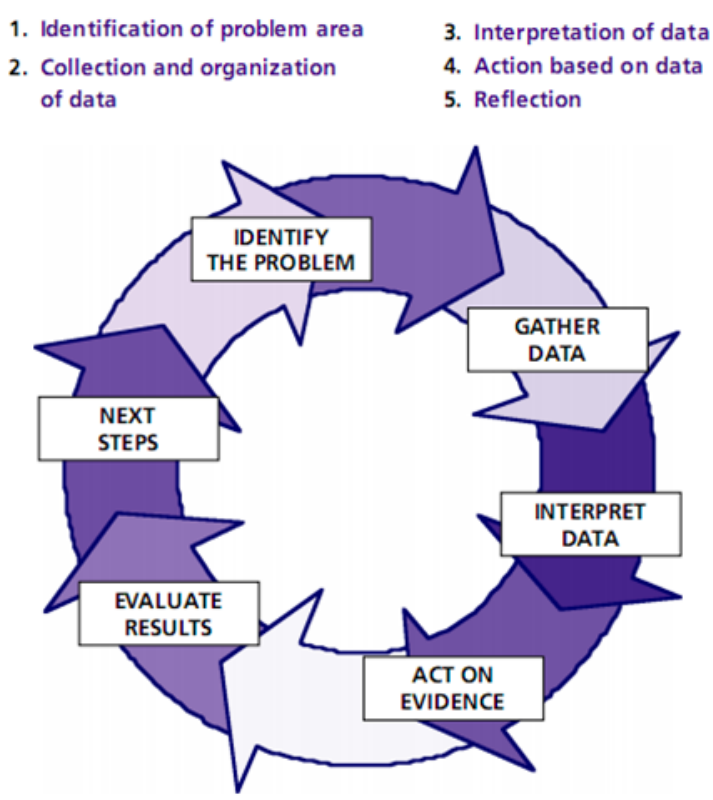

Figure1. Action research cycle (Ferrance, 2000)

Meanwhile, another action research design, consisting of only four steps (Plan, Act, Observe, and Reflect) is also favored by Cohen et al. (2001); Gall et al. (2007), and Sugiyono (2009) in which each of the four steps is further subdivided into two activities which are complex and inter-related. Farrance's model was therefore chosen and used because of the simplicity and relevance to the current study.

\subsection{Research Subjects (Participants)}

There were thirty-two randomly selected students, who were willing to fully take part in the study. They were taken from the students of College of Economics and Business Studies, Stikubank University (UNISBANK) Semarang. They were all majoring in Accounting, and had passed the ESP (English for Specific Purposes) course. They were committed to completing all the task-based assignments as they wanted to improve their academic writing skills.

The assignments consist of 21 links, namely (1) Pre-Test, (2) Rhetorical strategy 1, (3) Rhetorical strategy 2, (4) Rhetorical strategy 3, (5) Rhetorical strategy 4, (6) Rhetorical strategy 5, (7) Rhetorical strategy 6, (8) Text analysis 1, (9) Text analysis 2, (10) Text analysis 3, (11) Post-Test 1, (12) Text analysis 4, (13) Text analysis 5, (14) Text analysis 6, (15) Post-Test 2, (16) Academic writing practice 1 (17) Academic writing practice 2 (18) Academic writing practice 3, (19) Academic writing practice 4, (20) Post-Test 3, and (21) Online Survey-Survey Monkey.

Displayed below is a list of links on which the participants would click in order to complete the program specifically designed for online use by the students who have completed the ESP Course: 


\begin{tabular}{|c|c|c|c|}
\hline Name & Date modified & Type & Size \\
\hline 2) Academic Writing Practice 1 & 6/22/2016 12:07 PM & Question Writer Q... & $257 \mathrm{~KB}$ \\
\hline (2) Academic Writing practice 2 & 6/22/2016 8:44 AM & Question Writer Q... & $245 \mathrm{~KB}$ \\
\hline 2) Academic Writing practice 3 & 6/19/2016 10:28 AM & Question Writer Q... & $88 \mathrm{~KB}$ \\
\hline Q) Academic Writing practice 4 & 6/20/2016 8:36 AM & Question Writer Q... & $88 \mathrm{~KB}$ \\
\hline Q Post-Test 1 & $6 / 22 / 20168: 29 \mathrm{AM}$ & Question Writer Q... & $243 \mathrm{~KB}$ \\
\hline Q Post-Test 2 & 6/22/2016 8:28 AM & Question Writer Q... & $252 \mathrm{~KB}$ \\
\hline Q Post-Test 3 & $6 / 22 / 20168: 29 \mathrm{AM}$ & Question Writer Q... & $243 \mathrm{~KB}$ \\
\hline (2) Pre-test & $6 / 22 / 20168: 26$ AM & Question Writer Q... & $250 \mathrm{~KB}$ \\
\hline Q Rhetorical Strategy 1 & $6 / 23 / 201610: 49$ AM & Question Writer Q... & $245 \mathrm{~KB}$ \\
\hline 9. Rhetorical Strategy 2 & $6 / 23 / 201610: 10 \mathrm{AM}$ & Question Writer Q... & $88 \mathrm{~KB}$ \\
\hline 9. Rhetorical Strategy 3 & 6/24/2016 9:22 AM & Question Writer Q... & $88 \mathrm{~KB}$ \\
\hline Q Rhetorical Strategy 4 & 6/27/2016 10:01 AM & Question Writer Q... & $95 \mathrm{~KB}$ \\
\hline 9. Rhetorical Strategy 5 & $6 / 27 / 201610: 26 \mathrm{AM}$ & Question Writer Q... & $87 \mathrm{~KB}$ \\
\hline 9. Rhetorical Strategy 6 & $6 / 27 / 201610: 32 \mathrm{AM}$ & Question Writer Q... & $224 \mathrm{~KB}$ \\
\hline (2) Text Analysis 1 & 6/22/2016 8:30 AM & Question Writer Q... & $697 \mathrm{~KB}$ \\
\hline (2) Text Analysis 2 & 6/22/2016 8:31 AM & Question Writer Q... & $1,740 \mathrm{~KB}$ \\
\hline (2) Text Analysis 3 & 6/22/2016 8:34 AM & Question Writer Q... & $368 \mathrm{~KB}$ \\
\hline (2) Text Analysis 4 & 6/22/2016 8:44 AM & Question Writer Q... & $413 \mathrm{~KB}$ \\
\hline (2) Text Analysis 5 & $6 / 22 / 20168: 36 \mathrm{AM}$ & Question Writer Q... & $415 \mathrm{~KB}$ \\
\hline 9) Text Analysis 6 & 6/22/2016 8:36 AM & Question Writer Q... & $630 \mathrm{~KB}$ \\
\hline
\end{tabular}

\subsection{Data Collection}

Thirty-two (32) research participants were briefed prior to the research undertaking. They were asked to get access to the online writing exercises twice a week on Mondays and Thursdays. Each lasted 60-90 minutes depending on the types of task-based assignments. The task could be accessed any time during the day (Monday and Thursday) at https:// drpsugeng.edublogs.org. The students' completed assignments were automatically scored and directly sent to the inbox of the researcher's email. However, for essay evaluation, Writing Contest: Essay Rubric was used to assess the essays written online by the students.

\subsection{Data Analysis}

In Cycle 1, the scores for Pre-Test were tabulated in interval ranges of 80-100; 60-79; 40-59; and $\leq 39$ in order to come up with the frequency for each range leading to its percentage. A post-test was administered at the end of Cycle 1-in which the participants had completed assignments on Rhetorical Strategy (1-6) and Text Analysis (1-3) as an Act of Evidence (Action Based on Data), the results of which were tabulated similarly to the pre-test as Evaluative Resuts towards the Next Steps (Cycle 2) in which the Post Test 1 functioned as the pre-test for Cycle 2.

Similar tabulation of scores was performed for the results of Post-Test 2 upon completion of Text Analysis (3-6), leading to Cycle 3 in which Post-Test 2 functioned as the Pre-test for Cycle 3, ending up in Post-Test 3 upon completion of Academic Writing Practice (1-4). Each cycle was observed as evaluative results.

Finally, the three cycles were compared to one another to see the fluctuation of scores, mean scores and percentages for each cycle. The effectiveness of the newly designed mode of learning could be seen whether or not there was an increase in the mean score and the mastery learning (Score= 61). In other words, the pretest as an indication of the present condition was compared with Post-test 1, Post- test 2 and Post- test 3 in terms of scores in individual ranges, the mean scores and the passing grade (Score: 61), that is, how many participants scored below 61 and how many scored above 61. A survey was also conducted to find out the students' enthusiasm and attitudes towards the treatments.

\section{Results and Discussion}

There were twenty sessions that each participant had to complete; nine treatments after the pre-test, ending up in Post-Test 1 where Observation 1 (evaluative results) was performed. Three other treatments were undertaken, resulting in Post-Test 2 of which the results functioned as Observation 2. Furthermore, four other treatments were performed, resulting in Observation 3 (Post-Test 3). Below are details of each cycle implementation: 


\subsection{Cycle 1}

The Pre-Test which was conducted at the beginning of Cycle 1 could be viewed as identification of problem area in which the results (scores) are presented in Table 1 as follows:

Table 1. Frequency distribution of the initial condition (Pre-Test Scores)

\begin{tabular}{llll}
\hline No & Interval & Frequency & Percentage \\
\hline 1 & $80-100$ & 9 & $28 \%$ \\
2 & $60-79$ & 5 & $16 \%$ \\
3 & $40-59$ & 16 & $50 \%$ \\
4 & $\leq 39$ & 2 & $6 \%$ \\
& Total & $\mathbf{3 2}$ & $\mathbf{1 0 0 \%}$ \\
\hline
\end{tabular}

Table 1 indicates that the students' writing skills were quite low. Only $50 \%$ of them scored in the score range of 40-59 and 6\% scored less than 39. These results show that the students had somewhat low levels of writing competence. Meanwhile, they need the writing skills to cope with the demands of the present era of high levels of information and communication.

As previously mentioned, the Pre-Test-indicating the current condition-was followed by 6 treatments on rhetorical strategy in accordance with the text genres approved for college level, namely (1) hortatory exposition, (2) argumentative essay, (3) procedural text, (4) review text, (5) news item and (6) descriptive text.

The six treatments focused on consolidation of knowledge on text writing with respect to various genres. The next activities were completion of the series of text analysis to strengthen the writing skills, including the practice of writing essays. Cycle 1 ended with Post-Test. The scores of Post-Test 1are tabulated as follows:

Table 2. Frequency distribution of post-test 1 scores in cycle 1

\begin{tabular}{llll}
\hline No & Interval & Frequency & Percentage \\
\hline 1 & $80-100$ & 9 & $28 \%$ \\
2 & $61-79$ & 7 & $22 \%$ \\
3 & $40-60$ & 10 & $31 \%$ \\
4 & $\leq 39$ & 6 & $19 \%$ \\
& Total & $\mathbf{3 2}$ & $\mathbf{1 0 0 \%}$ \\
\hline
\end{tabular}

As indicated in Table 2, half of the respondents (50\%) managed to achieve the passing grade of (61) and the other $50 \%$ (16 participants) got scores below the passing grade. This indicated that there was an increase of the number of students $(14 \%)$ who managed to achieve the passing grade as compared with the initial condition. However, if viewed from the mean score, the Post-Test was only 61, while the Pre-Test (the initial condition) was 62.

In terms of scores, as compared to the initial condition (Pre-Test), the learning process through the online mode underwent an improvement of the students' writing skills as indicated in Table 3 below:

Table 3. Reflection of scores in cycle 1

\begin{tabular}{lllll}
\hline No & Remark & Initial Condition & Cycle I & Percentage \\
\hline 1 & The lowest score & 28 & 26 & $7 \%$ down \\
2 & The highest score & 93 & 95 & $2 \%$ up \\
3 & Mean & 62 & 61 & $1 \%$ down \\
4 & $\begin{array}{l}\text { The number of SS achieving scores above the passing } \\
\text { grade (61) }\end{array}$ & 14 & 16 & $14 \%$ up \\
5 & $\begin{array}{l}\text { The number of SS achieving scores below the passing } \\
\text { grade (61) }\end{array}$ & 18 & 16 & $11 \%$ down \\
\hline
\end{tabular}


In Cycle 1, some participants made some errors in doing the assignments. They resubmitted the results, meaning that they did the assignments more than once. In order to be fair, the researcher had to select the third submission for those who did the assignments more than once. Future attempts may be made in such a way that the participants can only submit once for each type of assignment.

Table 3 showed that concerning the lowest score in the initial condition, it decreased by $7 \%$ compared with the lowest score in Cycle 1, namely from 28 to 26 . However, in terms of the highest score, it increased by $2 \%$ from 93 to 95 . Meanwhile the mean score decreased by $1 \%$ from 62 to 61 . The number of SS achieving scores above the passing grade of (61) increased by $14 \%$ from 14 to 16 participants, which showed a positive trend. Furthermore, the number of SS achieving scores above the passing grade (61) decreased by $11 \%$ from 18 to 16 participants, which also showed a positive trend.

\subsection{Cycle 2}

The completion of Cycle 1 indicated that there was an increase in the students' achievement. However, the researcher still wondered about the $50 \%$ of the respondents who fell below the passing grade. The next identified problem was what happened to this 50\% students falling below the passing grade. Therefore the scores in Cycle 1 become the pre-test scores in Cycle 2.

On completion of the treatments in Cycle 2, that is doing 3 assignments (Text Analysis), the participants ended up with Post-Test 2, the scores of which are tabulated in Table 4 below:

Table 4. Frequency distribution of post-test 2 scores in cycle 2

\begin{tabular}{llll}
\hline No & Interval & Frequency & Percentage \\
\hline 1 & $80-100$ & 14 & $44 \%$ \\
2 & $61-79$ & 6 & $19 \%$ \\
3 & $40-60$ & 11 & $34 \%$ \\
4 & $\leq 39$ & 1 & $3 \%$ \\
& Total & $\mathbf{3 2}$ & $\mathbf{1 0 0 \%}$ \\
\hline
\end{tabular}

Table 4 indicate that the number of participants who scored above or the same as 61 were $20(63 \%)$. The rest (37\%) were below the score of 61 . This shows a good trend of learning development as compared with Cycle 1 . The two cycles can be reflected in Table 5 .

Table 5. Reflection of scores in cycle 2

\begin{tabular}{lllll}
\hline No & Remark & Cycle 1 & Cycle 2 & Percentage \\
\hline 1 & The lowest score & 26 & 38 & $46 \% \mathrm{Up}$ \\
2 & The highest score & 95 & 98 & $3 \% \mathrm{Up}$ \\
3 & Mean Score & 61 & 71 & $16 \% \mathrm{Up}$ \\
4 & The number of students with scores above the passing grade of 61 & 16 & 20 & $25 \% \mathrm{Up}$ \\
5 & The number of students with scores below the passing grade of 61 & 16 & 12 & $25 \%$ Down \\
\hline
\end{tabular}

Table 5 shows that concerning the lowest score in Cycle 1, it increased by $46 \%$ compared with the lowest score in Cycle 2, namely from 26 to 38 . However, in terms of the highest score, it increased by $3 \%$ from 95 to 98 . Meanwhile the mean score increased by $16 \%$ from 61 to 71 . The number of SS achieving scores above the passing grade of (61) increased by $25 \%$ from 16 to 20 participants, which showed a positive trend. Furthermore, the number of SS achieving scores below the passing grade (61) decreased by $25 \%$ from 16 to 12 participants, which also showed another positive trend.

\subsection{Cycle 3}

Despite the fact that Action Research may take two cycle of treatment, the current study took three cycles in order for the results (decision and recommendations) to be more convincing. Likewise, the pre-test for Cycle 3 was Post-Test 2. 
In Cycle 6, the treatments were four assignments in Academic Writing Practice (1-4). The frequency distribution of scores in Cycle 3 is presented in Table 6 below:

Table 6. Frequency distribution of scores in cycle 3

\begin{tabular}{llll}
\hline No & Interval & Frequency & Percentage \\
\hline 1 & $80-100$ & 17 & $53 \%$ \\
2 & $61-79$ & 14 & $44 \%$ \\
3 & $40-60$ & 1 & $3 \%$ \\
4 & $\leq 39$ & 0 & $0 \%$ \\
& Total & 32 & $100 \%$ \\
\hline
\end{tabular}

Table 6 shows that $97 \%$ of the participants (students) managed to achieve scores the same as or above the passing grade of 61 . Meanwhile, the rest (3\%) fell below the passing grade. This means that there was a positive tendency that students using the task-based assignment delivered online will progress significantly. The three cycles can be reflected in Table 7 as follows:

Table 7. Reflection of score in cycle 3

\begin{tabular}{lllll}
\hline No & Remark & Cycle 2 & Cycle 3 & Percentage \\
\hline 1 & The lowest score & 38 & 55 & $45 \% \mathrm{Up}$ \\
2 & The highest score & 98 & 100 & $2 \% \mathrm{Up}$ \\
3 & Mean score & 71 & 81 & $14 \% \mathrm{Up}$ \\
4 & The number of students with scores above the passing grade of 61 & 20 & 31 & $55 \% \mathrm{Up}$ \\
5 & The number of students with scores below the passing grade of 61 & 12 & 1 & $92 \%$ Down \\
\hline
\end{tabular}

Cycle 3 showed significant progress of the treatment. As reflected in Table 7, the lowest score increased significantly by $45 \%$, from score 38 in Cycle 2 to 55 in Cycle 3 . However, the highest score increased slightly by $2 \%$, from 98 in Cycle 2 to 100 in Cycle 3. Meanwhile the mean score increased considerably of $14 \%$, from 71 in Cycle 2 to 81 in Cycle 3. The number of SS achieving scores above the passing grade (61) increased by55\% from 20 to 31 participants, which showed a positive trend. Furthermore, the number of SS achieving scores below the passing grade (61) decreased by $25 \%$ from 12 to 1 participants, which also showed another positive trend.

Combined Cycles $(1,2$, and 3 ) represent a clear improvement of the academic writing skills of the participants (students) as shown in Table 8 below:

Table 8. Reflection of score from the initial condition to cycle 3

\begin{tabular}{lllllll}
\hline No & Remark & $\begin{array}{l}\text { Initial } \\
\text { Condition } \\
\text { (Pre-Test) }\end{array}$ & $\begin{array}{l}\text { Cycle } \\
\mathbf{1}\end{array}$ & $\begin{array}{l}\text { Cycle } \\
\mathbf{2}\end{array}$ & $\begin{array}{l}\text { Cycle } \\
\mathbf{3}\end{array}$ & $\begin{array}{l}\text { Percentage of } \\
\text { Improvement }\end{array}$ \\
\hline 1 & The lowest score & $\mathbf{2 8}$ & 26 & 38 & $\mathbf{5 5}$ & $96 \% \mathrm{Up}$ \\
2 & The highest score & $\mathbf{9 3}$ & 95 & 98 & $\mathbf{1 0 0}$ & $8 \% \mathrm{Up}$ \\
3 & Mean score & $\mathbf{6 2}$ & 61 & 71 & $\mathbf{8 1}$ & $31 \% \mathrm{Up}$ \\
4 & $\begin{array}{l}\text { The number of students with scores above } \\
\text { the passing grade of } 61\end{array}$ & $\mathbf{1 4}$ & 16 & 20 & $\mathbf{3 1}$ & $121 \% \mathrm{Up}$ \\
& $\begin{array}{l}\text { The number of students with scores below } \\
\text { the passing grade of } 61\end{array}$ & $\mathbf{1 8}$ & 16 & 12 & $\mathbf{1}$ & $94 \%$ Down \\
\hline
\end{tabular}

As reflected in Table 8, the academic writing skills of the participants (students) were enhanced and improved from Cycle to Cycle. The lowest score increased significantly by $96 \%$ from 28 in Pre-Test to 55 in Post-Test 3. However, only $8 \%$ increase occurred in the highest score, from 93 to 100 . Mean score increased by $31 \%$, from 


\section{2 in Pre-test to 81 in Post Test 3 (Cycle 3)}

Thus, software application of this type, though originally created for testing, can be used to improve or enhance writing skills by integrating task-based assignments which are designed in such a way as to achieve the basic competence The students can get direct feedbacks on what they have done by a single click.

\subsection{Survey}

The survey was conducted to find out the participants' enthusiasms and attitudes towards the treatments. The results of the survey is presented in Table 9.

Table 9. Survey on Participants' Enthusiasm and Attitude

\begin{tabular}{|c|c|c|c|c|c|c|c|}
\hline No & Statement & 5 & 4 & 3 & 2 & & $\sum$ \\
\hline 1 & $\begin{array}{l}\text { Working / learning online is in accordance with the individual and privacy } \\
\text { principle }\end{array}$ & 30 & 2 & & & & 32 \\
\hline 2 & I feel comfortable learning or doing assignments online. & & 29 & 3 & & & 32 \\
\hline 3 & $\begin{array}{l}\text { I realize the gradual improvement of my writing skills on completion of each } \\
\text { exercise. }\end{array}$ & 2 & 28 & & 2 & & 32 \\
\hline 4 & In writing the essays in this assignment, I feel the pressure of time & 10 & 16 & 6 & & & 32 \\
\hline 5 & Other types of exercises are very challenging & 6 & 26 & & & & 32 \\
\hline
\end{tabular}

According to the survey, at a glance, it is clear that the participants responded with the positive attitude and enthusiasm toward the online mode of developing writing skills. On Item 1, for example, the statement 'Working / learning online is in accordance with the individual and privacy principle." was responded to positively by 30 participants (93.75\%), while the rest, 2 (6.25\%) participants were more cautious and chose 'agree'. With respect to the comfort of doing the online assignments, 29 participants (90.625\%) agreed that they felt comfortable to do the online assignments, the rest, 3 participants chose abstain. This implies that there was no problem with computer literacy among the participants. Most of the participants $(87.5 \%)$ agreed that they realize that their writing skills improved gradually upon completion of all the assignments. Two (6.25\%) participants fully agreed to this, whereas the other two (6.25\%) participants chose abstain. Thus, the majority of participants (by average $71.094 \%$ ) responded positively to the online mode of task-based assignments, calculated on the basis of 'fully agree' and 'agree' responses.

The period of time for the assignments can be set, for example, $60^{\prime}$ or $90^{\prime}$ according to the examiner's perception with respect to how much time is required to complete each task. However, the timing which was always showing every now and again turned out to be stressful to the participants, especially during the writing the essays. Ten participants (31.25\%) fully agreed to this fact; the other $16(50 \%)$ agreed and $6(18.75)$ participants abstained.

The assignments were of various forms, such as multiple choice, partial credit, matching, and sequencing apart from the essays which were the final goal. When asked to comment on these various forms, 26 participants $(81.25 \%)$ agreed that various forms of assignments were challenging. The other six participants expressed full agreement. This supports the findings of a research report that online assignments are both challenging and motivating (Purwanto, 2015).

\section{Conclusion and Recommendations}

Learning module on academic writing can be integrated into a software application system, which has proven to be an effective way to improve academic writing skills employing the online mode of learning with minimal supervision. In other words, it supports independent learning model. With respect to the findings of the current study, several recommendations are offered as follows:

- Computer literacy of both the students and the teachers should be updated and upgraded at all times since internet world has offered unlimited experience of getting knowledge through online modes of learning.

- Online assignments, despite their great advantages, have one major disadvantage. Other people may do the tasks instead of the real students. Therefore honesty is highly prioritized in online modes of learning and teaching. 
- With respect to the development of writing skills, the role of a teacher is still dominant, especially with regard to scoring or grading the essays. The software can only grade or score the objective tests. Tests that require creativity and self-expression can only be scored or graded manually by adopting a rubric of relevance.

\section{Acknowledgments}

Sincere thanks and gratitude shall go to the Directorate General for Higher Education of the Republic of Indonesia for the research grant. The head of Research and Community Service Division, including her helpful staff members, who have helped complete the administrative procedures especially with respect to the Financial Report for this research undertaking. Special thanks shall also go to the students of Economics and Business Studies Major who had been willing to participate in the research with only little vouchers.

\section{References}

Antara News. com. (2011) Retrieved April 2014, from http://www.antaranews.com/berita/252005/indonesia-berada-di-peringkat-34-dari-44-negara-pengguna-bah asa-inggris

Cohen, L., Manion, L., \& Morrison, K. (2001) Research Methods in Education (5th Ed). New York: Routledge Falmer.

EF-English Proficiency Index. (2011) Retrieved April 2014, from http://www.ef.co.id/epi

Farrance, E. (2000). Action Research. Rode Island, UAS: LAB Brown University.

Gall, M. D., Gall. J. P., \& Borg, W. R. (2007). Educational research: An introduction (8th ed.). New York: Pearson.

International Data Corportion. (2010). Retrieved April 2014, from http://www.idc.com/about/viewpressrelease.jsp?containerId=prUS22617910

Lingzhu, Ji. (2009), Genre-based Approach for Teacing English Factual Writing Retrieved May 31, 2015, from http://www.hlmag.co.uk/apr09/mar02/htm

Purwanto, S. (2013). Aktivitas Facebooking di kalangan Mahasiswa FBIB Unisbank 2013. Unpublished Research. Semarang: LPPM Unisbank.

Purwanto, S. (2015). Evaluative Analysis of the Implementation of Mobile-Web Application System to Improve Academic English Writing Skills. A Paper Presented in International Seminar and Published in the Proceeding. Yogyakarta: Sanatadharma University.

Rahayu, E. Y., \& Februariyanti, H. (2015) Implementation of Online Reading Assessments to Encourage Reading Interests. English Language Teaching, 8(11), 197-206. http://dx.doi.org/10.5539/elt.v8n11p197

Sugiyono. (2009). Metode Penelitian Kuantitatif Kualitatif dan R\&D. Bandung: Alfabeta Bandung.

\section{Appendix}

\section{Sample of Assignment}

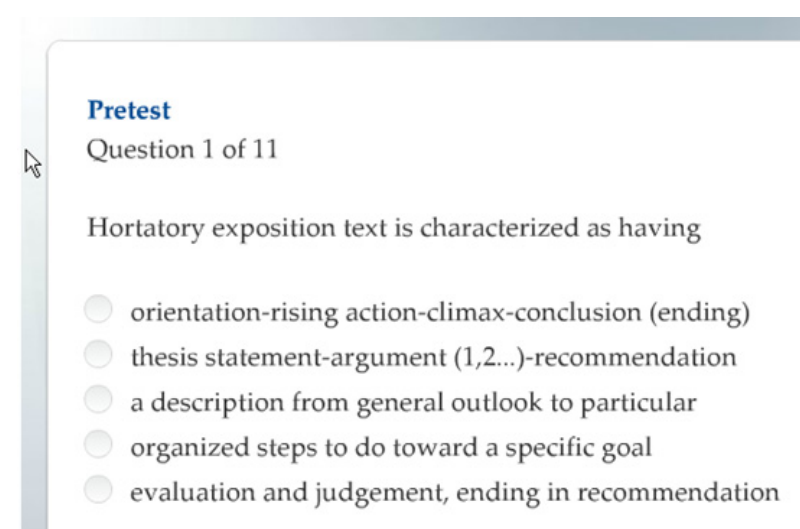


There are five types of questions, such as (1) multiple choice, (2) partial credits, (3) matching, (4) sequencing, and (5) essay. The participants (students) worked entirely online.

Except for the Essay Type, which had to be manually scored using a special rubric, all the other types of assignments were scored automatically and sent back to the researcher's email.

\title{
Sample of Essay Assignment
}

\author{
Rhetorical Strategy 3: Procedural Text \\ hQuestion 5 of 6
}

Write a notice that all classes today will be canceled due to the visit of the minister of education and culture. Assignments in place thereof can be seen in University Website. Don't forget to tell the students to submit the completed assignment no later than three days as of this notice

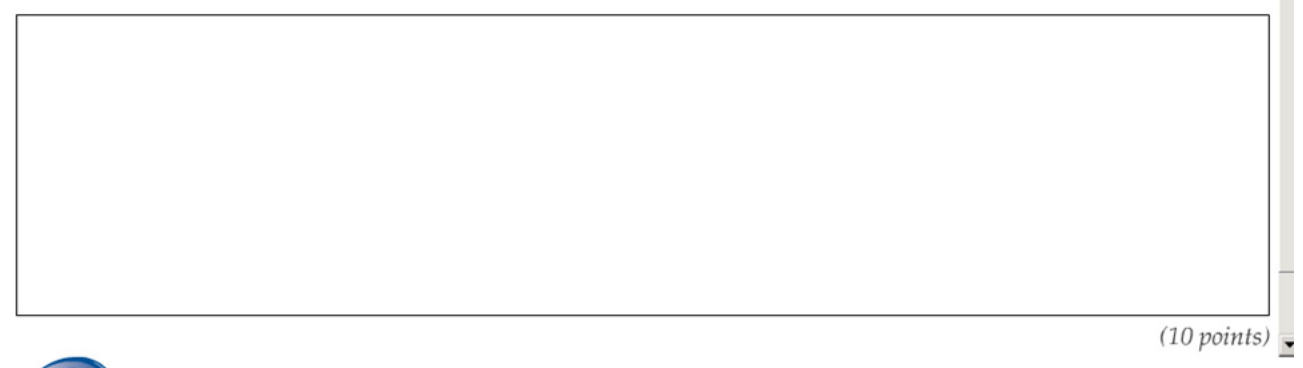

The students / participants directly typed on the box provided. All essays written by the participants (students) were returned to the researcher through email for further scoring employing a special rubric as follows:

\section{Writing Contest: Essay Rubric (Note 1)}

Contest definition of an Essay: AN ESSAY IS A WRITTEN COMPOSITION THAT EXPRESSES A POINT OF VIEW ON A TOPIC OF INTEREST TO THE AUTHOR.

Typewritten \& double-spaced 650 words $\min . / 1000$ words max.

$\underline{4}$

- Topic and argumentation is highly original and creative

- Title, introduction, details and conclusion all fit together

- Precise word choice (active verbs/vivid descriptive language/sensory descriptions) or imagery used

- Author's "voice" shows writer's excitement and makes writing fun to read

- Effective support provided by multiple research sources: statistics, quotations or other evidence

- All sources correctly cited and bibliography is complete

- **Language arouses emotions and makes reader think** (Contest Requirement)

- Correct paragraphing used

- Grammar, spelling and punctuation are correct.

$\underline{\mathbf{3}}$

- Topic and argumentation is original

- Most essay elements (title, introduction, details and conclusion) fit together

- Word choice is effective (active verbs/vivid descriptive language/sensory descriptions used)

- Author's "voice" is appealing and well-suited to the topic

- Viewpoint is supported by at least one research source: statistics, quotations or other evidence

- All sources correctly cited and bibliography is complete

- Correct paragraphing used

- Grammar, spelling and punctuation are correct.

$\underline{\mathbf{2}}$

- Topic and argumentation is not original, but presents reasonable discussion of both sides of an issue 
- At least two essay elements (title, introduction, details and conclusion) fit together

- Word choice includes some evidence of active verbs/vivid descriptive language/sensory descriptions

- Author's "voice" fades at times, but is acceptable to topic

- Research sources such as statistics, quotations or other evidence used but not cited

- Correct paragraphing used

- Most grammar, spelling and punctuation are correct.

1

- Topic and argument are difficult to understand

- Essay elements seem random and unrelated

- Words used incorrectly or overused words chosen

- "Voice" is distant or not appropriate to topic

- Paragraphing errors obvious

- Many grammar, spelling and punctuation errors

Upon collection of all the data (scores), the scores were then tabulated for further analysis as reported in this article. To make the findings more convincing, a survey (SurveyMonkey) was administered to find out the participants' enthusiasm and attitudes.

Note 1 . The total scores are finally multiplied by ten.

\section{Copyrights}

Copyright for this article is retained by the author(s), with first publication rights granted to the journal.

This is an open-access article distributed under the terms and conditions of the Creative Commons Attribution license (http://creativecommons.org/licenses/by/4.0/). 